\title{
MEASURING ISLAMIC FINANCIAL LITERACY AND DISCOVERING ITS RELATIONS WITH ENTREPRENEURSHIP AMONG UNIVERSITY STUDENTS IN TURKEY
}

İsmail DURAKa

\author{
Mehmet Akif ÖNCÜb \\ Osman KARTALc
}

\begin{abstract}
Financial Inclusion is one of the important parts of the financial system and Islamic Financial Literacy is a concept that requires knowledge about the Islamic financial system and can contribute positively to financial inclusion. This research has several goals. First, it aims to determine students' Islamic financial literacy levels in various faculties in a Turkish university. Secondly, it is aims to investigate the relationship between Islamic financial literacy level and financial attitude and behavior. Third, the impact of Islamic financial literacy on the entrepreneurial tendency is predicted. Finally, determining whether the level of Islamic financial literacy differs according to various demographic factors, especially the faculty variable, whether it is taking finance, or Islamic finance courses, is among the sub-objectives of the study. The universe of the research consists of students studying in the third and fourth grades of the faculties of business, engineering, and theology at Düzce University. 513 questionnaire data obtained within the scope of the research and data were analyzed with SPSS 25 statistical program. As a result of the research, Islamic Financial Knowledge levels and Islamic Financial literacy were gauged. It was determined that the Islamic Financial Knowledge levels and Literacy were quiet low among students and, students taking Islamic finance courses had high Islamic finance literacy. Also, looking attractiveness did not put a difference on Islamic financial knowledge, it provided a statistically significant relationship between those looking attractive to entrepreneurship and those not looking attractive to entrepreneur with respect to Islamic financial literacy level.
\end{abstract}

Keywords: Islamic Economy, Islamic Financial Literacy, Islamic Financial

a Asst. Prof., Düzce University, ismaildurak@duzce.edu.tr

b Prof., Duzce University, mehmetakifoncu@duzce.edu.tr

c Asst. Prof., Duzce University, osmankartal@duzce.edu.tr 
Knowledge, Entrepreneurship Intention, Entrepreneurship Tendency, Statistical Measurement.

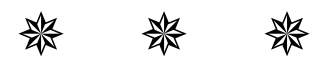

\section{ÜNIVERSITE ÖĞRENCILERININ İSLAMİ FINANSAL OKURYAZARLIĞININ ÖLÇÜLMESI VE GİRIŞiMCİLIK İLE İLIŞKISİ}

Finansal Erişim, başta dünya bankası olmak üzere birçok araştırmaya konu olmuş finansal sistemin önemli parçalarından biridir. Finansal sisteme dahil olma, gelişmekte olan ve az gelişmiş ülkelerde gelişmiş ülkelere göre daha azdır. Bunun pek çok nedeni olsa da önemli nedenlerinden biri finansal okuryazarlık düzeyinin düşük olmasıdır. Finansal okuryazarlık kavramı, doğru tasarrufları yapmak ve bu tasarrufları doğru yatırımlara yönlendirmek, sermaye ve para piyasaları hakkında bilgi sahibi olmak ve bu bilgileri doğru yorumlamak olarak düşünülebilir. Ayrıca, İslami Finansal Okuryazarlık, İslami finansal sistem hakkında bilgi gerektiren ve finansal erişime olumlu katkı sağlayabilen bir kavramdır. Hayatında İslami kuralları benimsemiş bireyler, faiz duyarlılığının yanı sıra İslami finansal araçlar ve kurumlar hakkında yeterli bilgiye sahip olmadıkça birikimlerini finansal sisteme dahil edemezler. Bu nedenle, insanların İslami finansal okuryazarlık düzeylerinin belirlenmesi, İslami finansal araçlar ve kurumlar hakkındaki bilgi düzeyinin yükseltilmesi hem tasarrufların ekonomiye dahil edilmesi hem de faiz sorununun giderilmesi açısından fayda sağlayacaktır. Literatürde finansal okuryazarlık, cinsiyet, yaş, eğitim, tasarruf davranışı girişimcilik gibi çeşitli değişkenlerle ilişkilendirilmiştir. Bunların arasında en can alıcı değişkenlerden biri, günümüzde üretime ve istihdama olan katkısı düşünüldüğünde makroekonomik sistemler açısından büyük önem taşıyan girişimciliktir. Hiç şüphesiz girişimcilerin ve girişimci adayları olan üniversite öğrencilerinin finansal bilgi ve okuryazarlık düzeyleri gelecekte katkıda bulunacakları işletmeler açısından çok önem arz eden faktörlerden biridir. Finansal okuryazarlıktan belli açılardan ayrılan bu kavram üzerine çeşitli araştırmalar yapılmıştır.

[Türkçe geniş öz çalış̧manın sonunda yer almaktadır.]

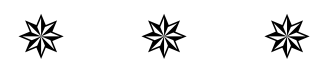

\section{Introduction}

Technological developments, increasing opportunities and highly competitive environment make it necessary to have knowledge in the financial field and to use this information rationally as in other fields with the awareness of how critical the concept of time. Technological advances, which enable individuals to carry out their financial affairs and transactions via computers, in the beginning, and today through smart phones and mobile 
applications, have made it necessary to have a good level of financial knowledge. In addition, the increase and developments in the variety of financial products and instruments have been another factor that necessitates people to have a certain level of financial knowledge. These situations and developments show that individuals who increase their financial knowledge level can better evaluate the opportunities and manage risks more accurately. Increasing the level of financial knowledge of individuals will contribute to the healthier development of their economy indirectly as well as their own financial decisions (Kaya, 2019).

The concept of financial literacy can be considered as making the right savings and directing these savings to the right investments, having information about the capital and money markets and interpreting this information accurately. On the other hand, the concept of Islamic finance imply that in addition to these features, having a belief in Islam and a life in accordance with this belief, having the knowledge and ability to use the basic concepts and dynamics of Islamic finance and to use them in accordance with the Islamic rules in all of their financial affairs and transactions (Karakuş, 2019). Individuals who have adopted Islamic rules in their lives cannot include their savings in the financial system unless they have enough information about Islamic financial instruments and institutions, besides they also have interest sensitivity. For this reason, determining the levels of Islamic financial literacy of people, improving the level of knowledge about Islamic financial instruments and institutions will benefit both in terms of including savings into the economy and eliminating the interest problem (Ylldırım, 2020). In the literature financial literacy have been linked various variables as gender, age, education, saving behavior entrepreneurship (Chen and Volpe; 1998; Clercq and Venter; 2009; Er et all., 2014; Potrich et all., 2015; Seyrek and Gül, 2017; Şahin and Barış, 2017). One of the crucial variables among these is entrepreneurship, which is of great importance in terms of macroeconomic systems, considering its contribution to production and employment today. Undoubtedly, financial knowledge levels of entrepreneurs and university students who are entrepreneur candidates are also one of the most important factors in terms of the health of the enterprises that they will create in the future. From this point of view, Islamic financial literacy levels of university students will be examined and their relationship with entrepreneurship will be investigated. In the following sections, conceptual background about the concept of Islamic Financial Literacy and a literature review will be presented. 
İsmail DURAK, Mehmet Akif ÖNCÜ \& Osman KARTAL

\section{A. Financial Literacy}

The concept of financial literacy has been a popular concept that many researches have been studied on it in finance literature. Evolving form this concept, in recent years, especially with the developments in Islamic financial institutions and instruments, besides the concept of financial literacy, the concept of Islamic financial literacy, has gained popularity in the literature.

\section{Islamic Financial Literacy}

As many discoveries, Islamic finance concept emerged with people 'demands linked to religious, economic and social reasons. People direct their financial transactions under moral factors as well as financial factors. Spiritual factors, on the other hand, emerge as religious beliefs. One of the biggest factors affecting individuals' lives, attitudes and behaviors is their religious beliefs. The fact that Islamic religion prohibits interest appears to be the most important factor in the evaluation of the financial system in terms of Islam (Ylldırım, 2020). With the global importance of oil, the need to manage Arab capital accumulating and the evaluation of the funds that individuals have accumulated for Hajj in some Islamic countries, Islamic finance concept and Islamic financial institutions have emerged and developed (TKBB, 2019). The development of Islamic finance in Turkey followed by the development of Islamic banking as it has acted in parallel in the world. In Turkey in the 1980s, developments occurring in Islamic finance and Islamic banking sector was first revealed as a special financial institution. Subsequently, it has been included in the same law as conventional banking and has been named "Participation Banking" with the decision of the Council of Ministers in 2005 (TKBB, 2019).

As it is a new and up-to-date concept, there is no clear definition of Islamic Financial Literacy yet generally accepted. This concept can also be interpreted as a new perspective brought to the concept of Financial Literacy (Bekereci, 2018). In this perspective, the concept of Islamic Financial Literacy, close to the definition of Financial Literacy in the literature has been defined various ways but quite parallel definitions. Some of them are the followings; "Having knowledge about Islamic financial transactions, understanding and interpreting the basis of Islamic finance and making decisions in this direction" Çömlekçi (2017, "the knowledge that individuals will have through education or experience in Islamic finance concepts and products" Abdullah and Anderson (2015), "Having information about Islamic products and services, individuals' ability to observe the basic principles of 
Islamic finance and to act in accordance with Islamic principles and rules while making financial decisions" Antara et al. (2016),) "the use of financial knowledge, attitude and behavior skills of individuals in the financial literacy definition in the literature on managing financial resources in line with Islamic principles" Siti et al. (2016).

Increasing the levels of Islamic financial literacy of individuals will enable the savings that remain idle due to religious concerns to be included in the financial system. In this way, it will be possible for individuals and institutions that have fund requests to obtain funds in accordance with religious rules and will create an effect that will increase the demand in this direction. In this context, it is very important to increase the levels of Islamic financial literacy of people. In summary, the incompatibility between the traditional financial system and the principles of Islamic finance, increasing the research on Islamic finance and taking care to develop the scale is of great importance for the development of Islamic finance and Islamic financial literacy. In this respect, in order to analyze Islamic finance in a holistic way, the provisions and basic information specified by Islamic law regarding financial markets should be assimilated by individuals (Bekereci, 2018). The development of Muslims' awareness of Islamic finance is not only economically beneficial, but also religiously compatible with their beliefs. The fact that Muslims do not care about the prohibition of interest and continue to use traditional financial products will cause the development of Islamic finance. Therefore, raising the level of Islamic financial literacy of the society, introducing Islamic financial instruments, raising the awareness of people on the subjects prohibited by Islam are also important according to the principle of "command goodness, avoid evil" (Ylldırım, 2020).

\section{Literature Review}

As stated in the previous sections of the study, there are a bulk of studies on financial literacy and limited number of studies on Islamic financial literacy. Under this section, information on other studies that are similar to our work in the related field and which contain foundations related to the subject will be included.

The results of the study conducted by Oseifuah in 2010 showed that financial literacy contributed positively to individuals' entrepreneurship skills and success. In parallel, in a study conducted by Abubakar in 2015, it was observed that the difficulty of accessing financial markets caused by the low level of financial literacy is an obstacle to entrepreneurship.

Clercq and Vender (2009) conducted a research on 903 students 
İsmail DURAK, Mehmet Akif ÖNCÜ \& Osman KARTAL

studying in South Africa in which they examined the effects of demographic factors on financial literacy. The results of the study revealed that there were significant differences between the financial literacy levels of individuals according to gender, race, age, language and income level.

Abdullah and Anderson (2015) examined the factors affecting individuals' levels of Islamic financial literacy on bank employees. As a result of the study, nine factors that affect Islamic financial literacy are introduced. They were that attitude towards Islamic financial products, perspective on banking tools, perspective on Islamic banking tools, asset planning and management, attitude towards individual financial management, effect of individual financial management, effect of families on Islamic financial products, factors determining securities investments and perspective on traditional banking products.

In another study by Abdillahi in 2015, the relationship between retirement planning and Islamic financial literacy was examined. As a result of the questionnaires conducted to 230 employees working at Malaysia Utara University, it was observed that there was a significant relationship between the participants' retirement plans and Islamic financial literacy levels, and their retirement plans were also affected by income and gender factors.

In the study carried out by Siti (2016), it was aimed to determine the demographic and psychological factors that have an impact on the levels of Islamic financial literacy of students studying at universities at the undergraduate level.

Similar to Abdillahi (2015), in this study, in the surveys conducted on 200 students studying at Utara University in Malaysia, it was determined that the psychological factors affecting Islamic financial literacy are financial satisfaction, religious values and hopelessness. In addition, it was observed that third grade students were at a higher financial literacy level than first and second grade students and male students were higher than female students.

Sardiana (2016) argued that Islamic financial literacy consists of three dimensions, including the ability to understand the characteristics of financial products, self-confidence and the level of knowledge about Islamic financial products. It was concluded that self-confidence and ability to understand Islamic financial products had no effect on the choice of Islamic financial products, but knowledge of Islamic financial products was highly effective.

In the study conducted by Er et al. (2014), the Islamic financial literacy 
levels of the Faculty of Theology and İBF students at Karadeniz Technical University were examined. As a result of the survey conducted on a total of 326 students, it was observed that the levels of Islamic financial literacy of students were generally low. Students with a relatively high level of Islamic financial literacy were those who studied at the Faculty of Theology, those with experience in trading participation banks, men of gender and those who took an activity or lesson on the Islamic economy.

In order to measure the levels of Islamic financial literacy, Çömlekçi (2017), was conducted a survey on 401 Participation bank customers who had accounts in participation banks. The findings of the study show that bank clients' Islamic financial literacy levels are low, as well as it has been revealed that their clients' levels of Islamic financial knowledge and Islamic financial literacy had significant differences according to the profession group, age, gender, education level and income level.

Bekereci et al. (2018) aimed to measure the effects of psychological factors such as piety, helplessness and financial satisfaction on the Islamic financial literacy levels of university students. It was revealed that Islamic financial literacy differs in terms of belief and financial practice. When the survey results were analyzed in terms of desperation, religiosity and financial satisfaction factors, it was revealed that while the relevance was meaningful and similar effects for both dimensions, the factor of helplessness in the level of faith tendency and the factor of financial satisfaction in the level of financial practice.

Karakuş (2019) provided information on the results of the survey conducted on individuals of different ages and professions living in Adana. It had been observed that men's financial information levels were higher than women and the participants are generally using their financial information. The findings obtained in the study regarding the levels of Islamic financial literacy showed that the level of Islamic financial literacy was quite low and that the participants had a perception that interest was not haram.

According to the analysis results of the survey conducted by Yildırım (2020) on 151 administrative and 212 academic staff working at Tokat Gaziosmanpaşa University, significant differences were found between the financial instrument knowledge level and gender. It was concluded that men had higher knowledge level about financial instruments than women. There was no significant difference between demographic factors such as gender, marital status, age, educational status and income range, and the level of Islamic financial literacy. The findings of the study showed that the academic 
İsmail DURAK, Mehmet Akif ÖNCÜ \& Osman KARTAL

financial literacy levels of academic and administrative staff working at Tokat Gaziosmanpaşa University are quite low.

When analyzed in terms of developed scales, in 2015, Hidajat and Hamdani stated that there was no scale to measure the level of Islamic financial literacy with an Islamic perspective and therefore it should be examined under 22 topics suggested by Islamic financial literacy. Antara (2016) proposed scales consisting of 23 questions to measure halal literacy and 17 questions to measure Islamic financial literacy levels.

\section{B. Research Methodology}

\section{Research Objectives and Model}

This research aims to investigates the level of Islamic financial literacy among university students and its relationship with entrepreneurship. Specifically, the study has the following objectives: a) researchers investigate the personal and departmental financial attitude, financial behavior, Islamic Financial Knowledge and Islamic financial literacy of a sample of Düzce University students by gender, faculty, family income, most used bank type. b) researchers examine relationships of the level of Islamic financial literacy and entrepreneurship intention, entrepreneurship attractiveness and some demographic data of Düzce University students. c) researchers examine the relationship between Düzce University students' financial attitudes, financial behavior, Islamic financial knowledge and their Islamic financial literacy level. In this direction, the model of study is shown in Figure 1.

Figure 1. Research Model

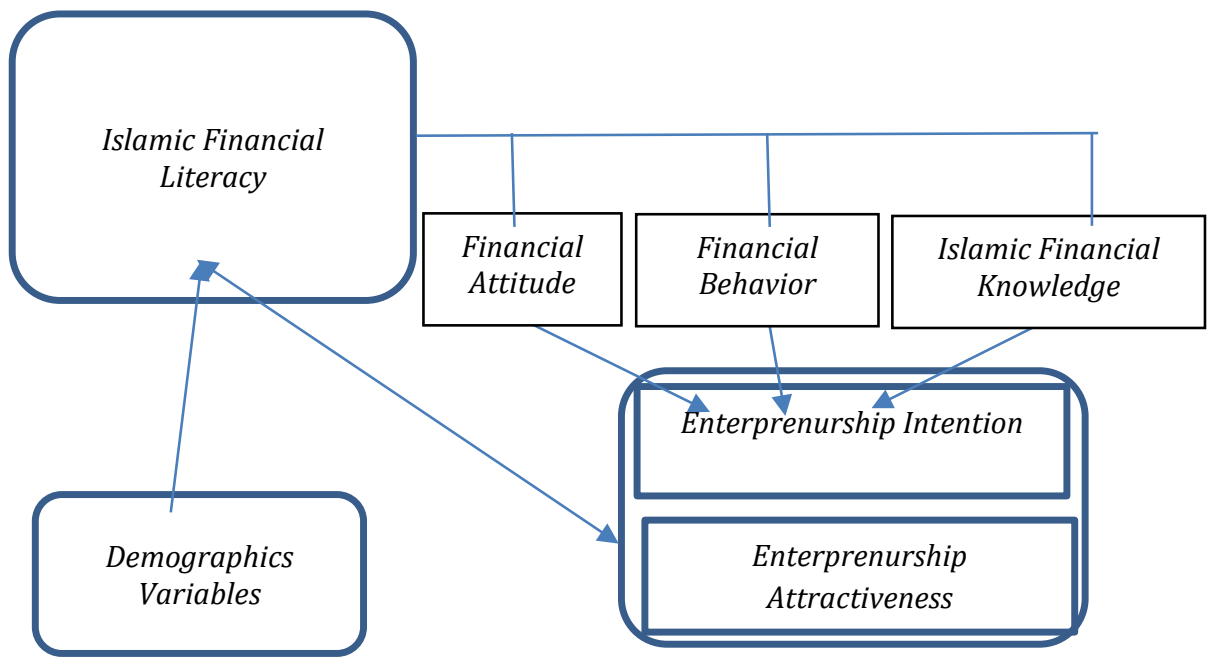




\section{Sample, Data Collection and Instruments}

The population of the research consists of students studying in the third and fourth grades of the selected faculties, namely Business Administration, Theology (Islamic) and Engineering, in Düzce University, Turkey. The reason why these three faculties are selected as samples is the idea of comparing a faculty student that may have a lower relation with Islamic Finance and Faculty of Business and Theology, who may have a high relation with Islamic Finance. Also, the reason why third and fourth grades of the students are selected is that finance, Islamic finance and entrepreneurship courses are usually offered in the third and fourth grades, and students are already attended at least one of these courses until these grades. To be more specific, students of the Faculty of Business may be better equipped in terms of finance, Islamic finance and entrepreneurship, and students of the Faculty of Theology could be more equipped in Islamic finance in terms of Islamic terminology, and students from other faculties (e.g., engineering faculty) may take less Islamic finance and relatively entrepreneurship courses. Thus, comparisons of these faculties could give meaningful results. The survey was conducted between 2-23 December 2019 and distributed online through an online survey development software and reached 553 participants. After the elimination of incomplete or erroneous data, total sample consisted of 512 respondents.

This research uses a comprehensive survey to gauge the level of Islamic Financial Literacy and major aspects of it. While there is not any consensus on the definition of financial literacy and consequently its dimensions (OECD; 2012; Atkinson and Messy, 2012; Agarwalla et al., 2013 and Potrich et al., 2018), likewise Islamic financial literacy and hereby its dimensions, it can be expressed that Islamic Financial Literacy includes financial attitudes, financial behavior, Islamic financial knowledge based on the literature (Atkinson and Messy, 2012; Coşkun, 2016; Çömlekçi, 2017; Er and Mutlu, 2017; Setiawati et all, 2018). The survey used in the research to collect data consists of by four blocks of questions. The first part includes questions to gauge the financial attitude of the participants, while the second part includes questions on financial behavior. As Çömlekçi (2017) did, questions in the first and second parts was created using Potrich et al. (2015) and in the third part, the level of Islamic financial knowledge was measured using Antara et al. (2016). The content validity and clarity of the constructed survey are verified by three academician who are expert and knowledgeable in Islamic Finance. The consistency and quality of the survey are also strengthened using reliability analysis by Cronbach's alpha. 
İsmail DURAK, Mehmet Akif ÖNCÜ \& Osman KARTAL

In brief, the first three parts of the survey participants are asked to answer 45 questions including 5 scale Likert-type questions (1=Strongly Disagree, 5=Strongly agree) of measuring their financial attitude (nine questions), financial behavior (twenty questions) and Islamic financial knowledge (sixteen questions, the first five of them for measuring basic Islamic financial knowledge, next eleven of them for measuring advanced Islamic financial knowledge and all of the sixteen questions used for measuring general Islamic financial knowledge). All these three parts questions used to gauge their Islamic Financial Literacy Level. For these 5 scale Likert-type questions in these three parts (financial attitudes, financial behavior, Islamic financial knowledge), only the 4th (agree), 5th (strongly agree) answers are accepted correct answer and 1 point has been attributed to them while others are attributed 0 point. In this way, the student who answered 1 question correctly achieved 1 point for each question from the financial attitude, financial behavior and Islamic financial knowledge part. Thus, a student could get maximum 9 point in financial attitude part, 20 point in financial behavior part, 16 point in Islamic financial literacy part and 45 point for all these three parts, which represents the maximum total points of Islamic financial literacy level. Financial attitude, financial behavior, Islamic financial knowledge and Islamic Financial Literacy score was calculated for all participants and this score was converted into percentage format. Accordingly, the higher the score a student got, the better is the level of the student. It is accepted that if the score calculated as a result of the responses given by the participants is below $60 \%$, it has low level; between $60 \%$ and $79 \%$, it has intermediate level; and $80 \%$ and above it has advanced level (Danes \& Hira, 1987; Chen and Volpe, 1998).

The last part of survey includes some questions related to socioeconomic and demographic variables of respondents as students' intention to entrepreneurship and attractiveness of entrepreneurship, having an entrepreneurial mother or father, taking or attending an Islamic financial course previously, gender, faculty, family income etc.

\section{Data Analysis and Results}

In the research, quantitative research method was used to achieve the aim of the study. In analyzing, frequency, percentage calculation, mean, and standard deviation, Cronbach's Alpha, ANOVA, T-test, and Chi-Square analyzes are used to fulfill the objectives of the study. First of all, reliability analyses of financial attitude, financial behavior general Islamic financial knowledge level and Islamic financial literacy were performed, and the 
Cronbach's Alpha value found out 0.879, 0.832, 0.907, and 0.896, respectively. Also, reliability analyses of other Islamic financial knowledge levels (basic and advanced levels) were calculated and resulted in 0.772, 0.888 , respectively., It is stated in the literature that the reliability coefficient should be above 0.7 level (Nunnally, 1967). In this context, it can be said that the data obtained from the research can be accepted as reliable. The level of Islamic financial literacy was measured by analyzing students' answers to questions on financial attitude, financial behavior and Islamic financial knowledge using the SPSS statistical package. Students' demographic characteristics data were also analyzed. The results are shown in Tables I.

Table 1: Demographic and Socioeconomic Characteristics of Participants

\begin{tabular}{|c|c|c|c|c|c|}
\hline Gender & Frequency & $\%$ & $\begin{array}{l}\text { Taken at least } \\
\text { one finance } \\
\text { course }\end{array}$ & Frequency & $\%$ \\
\hline Female & 228 & 44,5 & Yes & 314 & 61,3 \\
\hline Male & 284 & 55,5 & No & 198 & 38,7 \\
\hline Faculty & Frequency & $\%$ & $\begin{array}{l}\text { Taken at least } \\
\text { one Islamic } \\
\text { finance course }\end{array}$ & Frequency & $\%$ \\
\hline $\begin{array}{l}\text { Business } \\
\text { Administration }\end{array}$ & 322 & 62,9 & Yes & 77 & 15,0 \\
\hline Theology & 65 & 12,7 & No & 435 & 85,0 \\
\hline Engineering & 125 & 24,4 & $\begin{array}{l}\text { Attended at least } \\
\text { one Islamic } \\
\text { finance activity }\end{array}$ & Frequency & $\%$ \\
\hline Family income & Frequency & $\%$ & Yes & 90 & 17,6 \\
\hline $\begin{array}{l}\text { Less than } 1.500 \\
\text { (TL) }\end{array}$ & 80 & 15,6 & No & 422 & 82,4 \\
\hline $\begin{array}{l}1.501-3000 \\
\text { (TL) }\end{array}$ & 146 & 28,5 & $\begin{array}{l}\text { Taken at least } \\
\text { one } \\
\text { entrepreneurship } \\
\text { course }\end{array}$ & Frequency & $\%$ \\
\hline $\begin{array}{l}3.001-5.000 \\
\text { (TL) }\end{array}$ & 156 & 30,5 & Yes & 353 & 68,9 \\
\hline $\begin{array}{l}5.001-7.500 \\
\text { (TL) }\end{array}$ & 75 & 14,6 & No & 159 & 31,1 \\
\hline
\end{tabular}


İsmail DURAK, Mehmet Akif ÖNCÜ \& Osman KARTAL

\begin{tabular}{|c|c|c|c|c|c|}
\hline $\begin{array}{l}7.501-10.000 \\
\text { (TL) }\end{array}$ & 31 & 6,1 & $\begin{array}{c}\text { Students' } \\
\text { intention to } \\
\text { entrepreneurship }\end{array}$ & Frequency & $\%$ \\
\hline $\begin{array}{l}10.000(T L) \text { and } \\
\text { over }\end{array}$ & 24 & 4,7 & Yes & 374 & 73 \\
\hline $\begin{array}{l}\text { Most used bank } \\
\text { type }\end{array}$ & Frequency & $\%$ & No & 138 & 27 \\
\hline $\begin{array}{l}\text { Conventional } \\
\text { Bank }\end{array}$ & 482 & 94,1 & $\begin{array}{c}\text { Looking } \\
\text { attractive to } \\
\text { entrepreneurship }\end{array}$ & Frequency & $\%$ \\
\hline Islamic Bank & 29 & 5,7 & Yes & 454 & 88,7 \\
\hline Not Used & 1 & 0,2 & No & 58 & 11,3 \\
\hline $\begin{array}{l}\text { Having an } \\
\text { entrepreneurial } \\
\text { parent }\end{array}$ & Frequency & $\%$ & & & \\
\hline Yes & 120 & 23,4 & & & \\
\hline No & 392 & 76,6 & & & \\
\hline
\end{tabular}

Note: TL means Turkish Lira

As shown in Table 1, about $44,5 \%$ of students are female, and about $55,5 \%$ are male. The majority of them are educated business administration faculty $(\% 62,9)$ while engineering and theology students' percentages are 24,4 and 12,7 , respectively. Moreover, most of the students (\%95) frequently used conventional bank remaining (about 5\%) mainly used Islamic bank. In terms of the respondents who had taken at least one Islamic finance courses, about $85 \%$ had never taken the courses while leaving (15\%) have taken an Islamic finance course in an academic term. Similarly, in regard of the respondents who had attended at least one Islamic finance activity (e.g., conference, workshop etc.), nearly $83 \%$ of students had never attended the activity, the rest of them (about17\%) had attended the activity at least once. Furthermore, while a great majority of students looked attractive to entrepreneurship (about\%89), the rest of them (\%11) looked unattractive to entrepreneurship. Accordingly, nearly $73 \%$ students have intention to entrepreneurship, $\% 27$ of them do not have intention to entrepreneurship. Interestingly, these rates are inversely proportional to having an entrepreneurial family, which are about \%77 do not have an entrepreneur parent remaining (23\%) have. 
Table 2: Level of Islamic Financial Knowledge and Islamic Financial Literacy

\begin{tabular}{lccc}
\hline $\begin{array}{l}\text { Islamic financial } \\
\text { knowledge/literacy levels }\end{array}$ & Low (\%) & Medium (\%) & High (\%) \\
\hline Basic Islamic financial knowledge & $280(54,7)$ & $94(18,4)$ & $138(27,0)$ \\
\hline $\begin{array}{l}\text { Advanced Islamic financial } \\
\text { knowledge }\end{array}$ & $343(67,0)$ & $87(17,0)$ & $82(16,0)$ \\
\hline $\begin{array}{l}\text { General Islamic financial } \\
\text { knowledge }\end{array}$ & $360(70,3)$ & $81(15,8)$ & $71(13,9)$ \\
\hline Islamic financial literacy & $266(52,0)$ & $180(35,1)$ & $66(12,9)$ \\
\hline
\end{tabular}

Students' basic, advanced and general Islamic financial knowledge and Islamic financial literacy levels are gauged, and resultant are represented in Table 2. As can be seen from Table 2, slightly more than half of the students $(\% 54,7)$ had low level of basic Islamic financial knowledge and only \%27 of them had high level of basic Islamic financial knowledge. In terms of advanced Islamic financial knowledge, the situation got worse and about $\% 67$ of students had low level, and just $\% 16$ of them had high level. Like this situation, nearly three quarters of the students $(\% 70,3)$ had low level of general Islamic financial knowledge and merely about \%14 of them had high level of general Islamic financial knowledge. Accordingly, Islamic financial literacy level shows similar results. Over half of the students (\%52) had low level of Islamic financial literacy and only about \%13 of them had high level of Islamic financial literacy.

In Table 3, in order to determine whether there is any of the differences between the means of financial attitude and financial behavior with respect to Islamic financial knowledge levels and Islamic literacy levels are statistically significant, ANOVA analyses has been performed.

Table 3: ANOVA results for Financial Attitude, Financial Behavior, Level of Islamic Financial Knowledge and Islamic Financial Literacy

\begin{tabular}{llllllll}
\hline Variables & & $\begin{array}{l}\text { Variance } \\
\text { Source }\end{array}$ & $\begin{array}{l}\text { Sum of } \\
\text { Squares }\end{array}$ & & $\begin{array}{l}\text { Mean } \\
\text { Square }\end{array}$ & F & P \\
\hline $\begin{array}{l}\text { Basic Islamic } \\
\text { financial } \\
\text { knowledge }\end{array}$ & $\begin{array}{l}\text { Financial } \\
\text { Attitude }\end{array}$ & $\begin{array}{l}\text { Between } \\
\text { Groups }\end{array}$ & 29,86 & 2 & 14,93 & 4,22 &, 015 \\
\cline { 2 - 8 } & Financial & Within & 192,36 & 2 & 96,18 & 6,01 &, 003 \\
\hline $\begin{array}{l}\text { Advanced } \\
\text { Islamic } \\
\text { financial } \\
\text { knowledge }\end{array}$ & Financial & Getween & 22,25 & 2 & 11,13 & 3,13 &, 044 \\
\cline { 2 - 8 } & Attitude & Groups & & & & & \\
\hline
\end{tabular}


İsmail DURAK, Mehmet Akif ÖNCÜ \& Osman KARTAL

\begin{tabular}{|c|c|c|c|c|c|c|c|}
\hline \multirow{2}{*}{$\begin{array}{l}\text { General } \\
\text { Islamic } \\
\text { financial } \\
\text { knowledge }\end{array}$} & $\begin{array}{l}\text { Financial } \\
\text { Attitude }\end{array}$ & $\begin{array}{l}\text { Between } \\
\text { Groups }\end{array}$ & 28,48 & 2 & 14,24 & 4,03 & ,018 \\
\hline & $\begin{array}{l}\text { Financial } \\
\text { Behavior }\end{array}$ & $\begin{array}{l}\text { Within } \\
\text { Groups }\end{array}$ & 407,06 & 2 & 203,53 & 13,07 & ,000 \\
\hline \multirow{2}{*}{$\begin{array}{l}\text { Islamic } \\
\text { financial } \\
\text { literacy }\end{array}$} & $\begin{array}{l}\text { Financial } \\
\text { Attitude }\end{array}$ & $\begin{array}{l}\text { Between } \\
\text { Groups }\end{array}$ & 266,84 & 2 & 133,42 & 43,46 & ,000 \\
\hline & $\begin{array}{l}\text { Financial } \\
\text { Behavior }\end{array}$ & $\begin{array}{l}\text { Within } \\
\text { Groups }\end{array}$ & 2780,0 & 2 & 1390,0 & 127,4 & ,000 \\
\hline
\end{tabular}

The table 3 shows that the differences between the means of financial attitude of students with respect to basic Islamic financial knowledge $(\mathrm{F}=4.223, \mathrm{p}=0.015<0.05)$, advanced Islamic financial knowledge $(\mathrm{F}=3.133$, $\mathrm{p}=0.044<0.05)$, general Islamic financial knowledge $(\mathrm{F}=4.025$, $\mathrm{p}=0.018<0.05)$, Islamic financial literacy $(\mathrm{F}=43.458, \mathrm{p}=0,000<0.05)$ are statistically significant. Similarly, the differences between the means of financial behavior of students with respect to basic Islamic financial knowledge $(\mathrm{F}=6.013, \mathrm{p}=0.003<0.05)$, advanced Islamic financial knowledge $(\mathrm{F}=12.885, \mathrm{p}=0.000<0.05)$, general Islamic financial knowledge $(\mathrm{F}=13.067$, $\mathrm{p}=0.000<0.05)$, Islamic financial literacy $(\mathrm{F}=127.37, \mathrm{p}=0.000<0.05)$ are statistically significant.

According to the results of post-hoc tests (Games-Howell test used since test of homogeneity of variance is significant) to find the source of the differences of financial attitude with respect to basic Islamic financial knowledge levels, the difference arises from between low and high groups of basic Islamic financial knowledge. Also, the results of post-hoc tests (Tukey and Scheffe test used since test of homogeneity of variance is insignificant) to find the source of the differences of financial behavior with respect to basic Islamic financial knowledge levels, the difference resulted from between low and high groups and, medium and high groups of basic Islamic financial knowledge. Similar to the results of post-hoc tests for financial attitude-basic Islamic financial knowledge levels and financial behavior-basic Islamic financial knowledge levels, the consequences of post-hoc tests for financial attitude-advanced Islamic financial knowledge and financial behavioradvanced Islamic financial knowledge levels had completely the same results in terms of both used tests and outcomes for the sources of the differences.

Meanwhile, the results of post-hoc tests for financial attitude-general Islamic financial knowledge levels and financial behavior-general Islamic financial knowledge levels were entirely parallel to the financial attitudebasic Islamic financial knowledge levels, financial behavior-basic Islamic financial knowledge levels, the financial attitude-advanced Islamic financial 
knowledge levels, financial behavior- advanced Islamic financial knowledge levels. Moreover and importantly, to the results of post-hoc tests (GamesHowell test used for financial attitude-Islamic financial literacy levels and Tukey and Scheffe test used for financial behavior-Islamic financial literacy levels) to find the source of the differences of financial attitude -Islamic financial literacy levels and financial behavior-Islamic financial literacy levels, the difference arises from between all binary groups (low-high, lowmedium and low-high groups).

Table 4: ANOVA results for Faculty and Islamic Financial Knowledge and Islamic Financial Literacy

\begin{tabular}{|c|c|c|c|c|c|c|c|c|}
\hline Variables & FACULTY & Mean & $\begin{array}{l}\text { Variance } \\
\text { Source }\end{array}$ & $\begin{array}{l}\text { Sum of } \\
\text { Squares }\end{array}$ & df & $\begin{array}{l}\text { Mean } \\
\text { Square }\end{array}$ & $\mathbf{F}$ & $\mathbf{P}$ \\
\hline \multirow{3}{*}{ 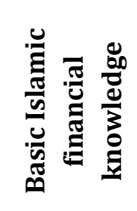 } & $\begin{array}{l}\text { Business } \\
\text { Administration }\end{array}$ & 2,35 & \multirow{3}{*}{$\begin{array}{l}\text { Between } \\
\text { Groups } \\
\text { Within } \\
\text { Groups }\end{array}$} & \multirow[t]{2}{*}{30,099} & \multirow[t]{2}{*}{2} & \multirow[t]{2}{*}{15,1} & \multirow{3}{*}{5,26} & \multirow{3}{*}{01} \\
\hline & Theology & 2,37 & & & & & & \\
\hline & Engineering & 1,80 & & 1455,6 & 509 & 2,86 & & \\
\hline \multirow{3}{*}{ 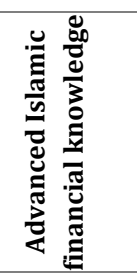 } & $\begin{array}{l}\text { Business } \\
\text { Administration }\end{array}$ & 4,34 & \multirow[t]{2}{*}{$\begin{array}{l}\text { Between } \\
\text { Groups }\end{array}$} & \multirow[t]{2}{*}{194,91} & \multirow[t]{2}{*}{2} & \multirow[t]{2}{*}{97,5} & \multirow{3}{*}{7,12} & \multirow{3}{*}{,00 } \\
\hline & Theology & 4,57 & & & & & & \\
\hline & Engineering & 3,10 & $\begin{array}{l}\text { Within } \\
\text { Groups }\end{array}$ & 6963,2 & 509 & 13,9 & & \\
\hline \multirow{3}{*}{ 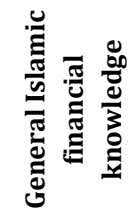 } & $\begin{array}{l}\text { Business } \\
\text { Administration }\end{array}$ & 6,69 & \multirow{3}{*}{$\begin{array}{l}\text { Between } \\
\text { Groups } \\
\text { Within } \\
\text { Groups }\end{array}$} & \multirow[t]{2}{*}{377,36} & \multirow[t]{2}{*}{2} & \multirow[t]{2}{*}{188,9} & \multirow{3}{*}{7,74} & \multirow{3}{*}{00} \\
\hline & Theology & 6,93 & & & & & & \\
\hline & Engineering & 4,90 & & 12408,3 & 509 & 24,4 & & \\
\hline \multirow{3}{*}{ 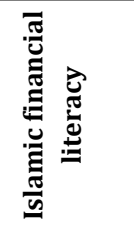 } & $\begin{array}{l}\text { Business } \\
\text { Administration }\end{array}$ & 26,42 & \multirow[t]{2}{*}{$\begin{array}{l}\text { Between } \\
\text { Groups }\end{array}$} & \multirow[t]{2}{*}{1910,8} & \multirow[t]{2}{*}{2} & \multirow[t]{2}{*}{955,4} & \multirow{3}{*}{15,9} & \multirow{3}{*}{00} \\
\hline & Theology & 27,57 & & & & & & \\
\hline & Engineering & 22,96 & $\begin{array}{l}\text { Within } \\
\text { Groups }\end{array}$ & 30671,7 & 509 & 60,3 & & \\
\hline
\end{tabular}

Table 4 addresses and displays that the differences of the means of faculties with respect to basic Islamic financial knowledge ( $F=5.263$, $\mathrm{p}=0.005<0.05)$, advanced Islamic financial knowledge $(\mathrm{F}=7.124$, $\mathrm{p}=0.001<0.05)$, general Islamic financial knowledge $(\mathrm{F}=7.740$, $\mathrm{p}=0.000<0.05)$, Islamic financial literacy $(\mathrm{F}=15.855, \mathrm{p}=0,000<0.05)$ are statistically significant. In order to find the source of the differences of the 
İsmail DURAK, Mehmet Akif ÖNCÜ \& Osman KARTAL

means of basic Islamic financial knowledge with respect to faculties, post-hoc tests (Tukey and Scheffe test used since test of homogeneity of variance is insignificant) performed and the results showed that the differences arises between Business Administration and Engineering faculties ( $\mathrm{p}=0.004)$. Also, according to the results of post-hoc tests (Games-Howell test used since test of homogeneity of variance is significant) to find the source of the differences of the means of advanced Islamic financial knowledge with respect to faculties, the difference resulted from between business Administration and engineering faculties $(\mathrm{p}=0.001)$, and between theology and engineering faculties ( $\mathrm{p}=0.049$ ).

Moreover, post-hoc tests (Tukey and Scheffe test used since test of homogeneity of variance is insignificant) exercised and the results showed that the differences of means of general Islamic financial knowledge with respect to faculties arises from between business administration and engineering faculties $(p=0.000)$ and also, theology and engineering faculties $(p=0.048)$. Furthermore, and the most important results of the post-hoc tests (Games-Howell test used since test of homogeneity of variance is significant) were obtained from the sources of differences of the means of Islamic financial literacy with respect to faculties. Similar to earlier scenario on the results of the ANOVA tests for advanced Islamic financial knowledge and general Islamic financial knowledge with respect to faculties, the differences of the means of Islamic financial literacy with respect to faculties resulted from between business administration and engineering faculties $(p=0.000)$, and between theology and engineering faculties ( $p=0.008$ ). In fact, as can be seen in Table 4, the means of Islamic financial knowledge levels and Islamic financial literacy with respect to faculties were given and the sources of differences could slightly be observed in the table as analyzed and reported by ANOVA tests.

Further analysis was made to see whether there are any differences between family income levels with respect to Islamic financial knowledge levels and Islamic financial literacy. According to ANOVA tests, there were not any differences between Islamic financial knowledge levels and Islamic financial literacy with respect to family income levels and so that the elaborated statistical analyses of this test do not included here.

As shown in Table 5, to find out whether male and female participants show difference in the Islamic financial knowledge levels and Islamic financial literacy, we run the analysis of t-test. As can be seen in the table, neither Islamic financial knowledge scores nor Islamic financial literacy 
score showed a difference in terms of gender. To realize the results of these tests obviously, the means of both male and female participants were presented in the same table, and it revealed that the means of both male and female were very close to each other in all the levels.

Table 5: T-Test between Gender vs. Islamic Financial Knowledge and Islamic Financial Literacy Level

\begin{tabular}{|c|c|c|c|c|c|c|c|c|}
\hline \multirow{3}{*}{ 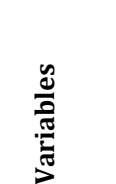 } & \multicolumn{2}{|c|}{ Means } & & \multirow{2}{*}{\multicolumn{2}{|c|}{$\begin{array}{l}\text { Levene's Test } \\
\text { for Equality of } \\
\text { Variances }\end{array}$}} & \multirow{2}{*}{\multicolumn{3}{|c|}{$\begin{array}{l}\text { T-test for Equality } \\
\text { of Means }\end{array}$}} \\
\hline & \multirow[t]{2}{*}{ Male } & \multirow[t]{2}{*}{ Female } & & & & & & \\
\hline & & & & $\mathbf{F}$ & Sig. & $\mathbf{t}$ & df & Sig. \\
\hline \multirow{2}{*}{ 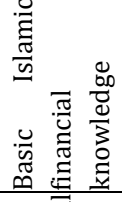 } & \multirow{2}{*}{2,17} & \multirow{2}{*}{2,30} & $\begin{array}{l}\text { Equal Variances } \\
\text { Assumed }\end{array}$ & 6,15 & 013 &,- 85 & 510 & ,40 \\
\hline & & & $\begin{array}{l}\text { Equal Variances } \\
\text { Not Assumed }\end{array}$ & & &,- 86 & $\begin{array}{l}502, \\
8\end{array}$ & ,39 \\
\hline \multirow{2}{*}{ 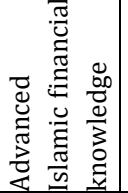 } & \multirow{2}{*}{4,20} & \multirow{2}{*}{4,16} & $\begin{array}{l}\text { Equal Variances } \\
\text { Assumed }\end{array}$ & ,53 & 466 & 11 & 510 & ,92 \\
\hline & & & $\begin{array}{l}\text { Equal Variances } \\
\text { Not Assumed }\end{array}$ & & & 11 & $\begin{array}{l}496, \\
0\end{array}$ & ,92 \\
\hline \multirow{2}{*}{ 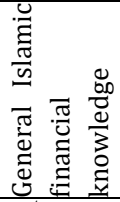 } & \multirow{2}{*}{6,37} & \multirow{2}{*}{6,46} & $\begin{array}{l}\text { Equal Variances } \\
\text { Assumed }\end{array}$ & 2,58 & 109 &,- 21 & 510 & ,83 \\
\hline & & & $\begin{array}{l}\text { Equal Variances } \\
\text { Not Assumed }\end{array}$ & & &,- 21 & $\begin{array}{l}502, \\
02\end{array}$ & ,83 \\
\hline \multirow{2}{*}{ 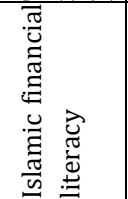 } & \multirow{2}{*}{26,19} & \multirow{2}{*}{26,43} & $\begin{array}{l}\text { Equal Variances } \\
\text { Assumed }\end{array}$ & 2,21 & 138 &,- 33 & 510 & ,74 \\
\hline & & & $\begin{array}{l}\text { Equal Variances } \\
\text { Not Assumed }\end{array}$ & & &,- 34 & $\begin{array}{l}503 \\
98\end{array}$ & ,74 \\
\hline
\end{tabular}

We also examine if scores are higher those of taken at least one Islamic finance course than those of not taken an Islamic finance course before. As presented in Table 6.

As it is clearly seen in the Table 6, the mean differences in all Islamic financial knowledge levels and Islamic financial literacy between those taking at least one Islamic finance course before and those not taking at least one Islamic finance course before are statistically significant. On average scores of participants those taken at least one Islamic finance course were pretty higher than those not taken at least one Islamic finance course in all Islamic financial knowledge levels and Islamic financial literacy. These results also supported and showed completely the same results with when 
İsmail DURAK, Mehmet Akif ÖNCÜ \& Osman KARTAL

Table 6: T-Test between taking Islamic finance course vs. Islamic financial knowledge and Islamic F-financial literacy Levels

\begin{tabular}{|c|c|c|c|c|c|c|c|c|}
\hline \multirow{2}{*}{$\frac{a}{\frac{d}{0}}$} & \multicolumn{2}{|c|}{$\begin{array}{l}\text { Means of taken at } \\
\text { least one Islamic } \\
\text { finance course }\end{array}$} & & \multicolumn{2}{|c|}{$\begin{array}{l}\text { Levene's Test } \\
\text { for Equality of } \\
\text { Variances }\end{array}$} & \multirow{2}{*}{$\begin{array}{l}\text { T-test } \\
\text { Means } \\
\mathrm{t}\end{array}$} & \multirow{2}{*}{$\begin{array}{r}\text { for } \\
\text { df }\end{array}$} & \multirow{2}{*}{$\begin{array}{c}\text { ity of } \\
\text { Sig. }\end{array}$} \\
\hline & Yes & No & & $\mathbf{F}$ & Sig. & & & \\
\hline 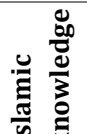 & 3,00 & 2,09 & $\begin{array}{l}\text { Equal } \\
\text { Variances } \\
\text { Assumed }\end{array}$ & 1,28 & ,26 & 4,40 & 510 & ,00 \\
\hline 莺 & & & $\begin{array}{l}\text { Equal } \\
\text { Variances } \\
\text { Not Assumed }\end{array}$ & & & 4,42 & 105,28 & ,00 \\
\hline 岂 & 6,29 & 3,81 & $\begin{array}{l}\text { Equal } \\
\text { Variances } \\
\text { Assumed }\end{array}$ & 9,80 & ,00 & 5,50 & 510 & ,00 \\
\hline 宽 & & & $\begin{array}{l}\text { Equal } \\
\text { Variances } \\
\text { Not Assumed }\end{array}$ & & & 6,16 & 116,39 & ,00 \\
\hline 泀 & 9,29 & 5,90 & $\begin{array}{l}\text { Equal } \\
\text { Variances } \\
\text { Assumed }\end{array}$ & 6,34 & ,01 & 5,64 & 510 &, 00 \\
\hline 苞 & & & $\begin{array}{l}\text { Equal } \\
\text { Variances } \\
\text { Not Assumed }\end{array}$ & & & 6,17 & 113,72 &, 00 \\
\hline 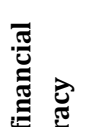 & 29,58 & 25,71 & $\begin{array}{l}\text { Equal } \\
\text { Variances } \\
\text { Assumed }\end{array}$ & 2,92 & ,09 & 3,98 & 510 & ,00 \\
\hline 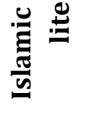 & & & $\begin{array}{l}\text { Equal } \\
\text { Variances } \\
\text { Not Assumed }\end{array}$ & & & 4,37 & 114,08 &, 00 \\
\hline
\end{tabular}

we tested if scores of those attended at least one Islamic finance activity were higher than those not attended at least one Islamic finance activity, and also we got almost similar results with when we examined whether scores are higher those of taken at least one finance course than those of not taken a finance course except basic Islamic financial knowledge score.

One of the compelling analyses were carried out to find if there were significant statistical relationship between the situation of looking attractive to entrepreneurship and Islamic financial knowledge levels and Islamic financial literacy in Table 7. The table highlights that there was not any 
Table 7: $\chi 2$ tests between looking attractive to entrepreneurship vs. Islamic financial knowledge levels and Islamic financial literacy

\begin{tabular}{|c|c|c|c|c|c|c|}
\hline \multirow{2}{*}{ Variables } & \multirow[t]{2}{*}{ Levels } & \multicolumn{3}{|c|}{ Looking attractive to entrepreneurship } & \multirow[t]{2}{*}{$\chi^{2}$} & \multirow[t]{2}{*}{$\mathbf{P}$} \\
\hline & & Yes & No & Total & & \\
\hline \multirow{4}{*}{$\begin{array}{l}\text { Basic Islamic } \\
\text { financial } \\
\text { knowledge }\end{array}$} & Low & 247 & 33 & 280 & \multirow[t]{4}{*}{0,264} & \multirow[t]{4}{*}{,0876 } \\
\hline & Medium & 83 & 11 & 94 & & \\
\hline & High & 124 & 14 & 138 & & \\
\hline & Total & $\begin{array}{l}454 \\
(88,7 \%)\end{array}$ & $58(11,3 \%)$ & $512(100 \%)$ & & \\
\hline \multirow{4}{*}{$\begin{array}{l}\text { Advanced } \\
\text { Islamic } \\
\text { financial } \\
\text { knowledge }\end{array}$} & Low & 306 & 37 & 343 & \multirow[t]{4}{*}{0,636} & \multirow[t]{4}{*}{,727 } \\
\hline & Medium & 75 & 12 & 87 & & \\
\hline & High & 73 & 9 & 82 & & \\
\hline & Total & $\begin{array}{l}454 \\
(88,7 \%)\end{array}$ & $58(11,3 \%)$ & $512(100 \%)$ & & \\
\hline \multirow{4}{*}{$\begin{array}{l}\text { General } \\
\text { Islamic } \\
\text { financial } \\
\text { knowledge }\end{array}$} & Low & 321 & 39 & 360 & \multirow[t]{4}{*}{0,300} & \multirow[t]{4}{*}{,861 } \\
\hline & Medium & 71 & 10 & 81 & & \\
\hline & High & 62 & 9 & 71 & & \\
\hline & Total & $\begin{array}{l}454 \\
(88,7 \%)\end{array}$ & $58(11,3 \%)$ & $512(100 \%)$ & & \\
\hline \multirow{4}{*}{$\begin{array}{l}\text { Islamic } \\
\text { financial } \\
\text { literacy }\end{array}$} & Low & 229 & 37 & 266 & \multirow[t]{4}{*}{7,603} & \multirow[t]{4}{*}{,022 } \\
\hline & Medium & 169 & 11 & 180 & & \\
\hline & High & 56 & 10 & 66 & & \\
\hline & Total & $\begin{array}{l}454 \\
(88,7 \%)\end{array}$ & $58(11,3 \%)$ & $51200 \%)$ & & \\
\hline
\end{tabular}

significant $(\mathrm{p}=0,05)$ statistical relationships between the situation of looking attractive to entrepreneurship and Islamic financial knowledge levels. On the other hand, there was just a statistically significant relationship between those looking attractive to entrepreneurship and those not looking attractive to entrepreneur with respect to Islamic financial literacy level. Students' intention to entrepreneurship resulted in the same consequences when we made further analyzes to find relationship between those having intention to entrepreneurship and those not having intention to entrepreneurship with respect to Islamic financial knowledge levels and Islamic financial literacy. 
İsmail DURAK, Mehmet Akif ÖNCÜ \& Osman KARTAL

\section{Conclusions}

Finance is one of the most important structure of development and financial inclusion is directly crucial to all nations and modern world. On the other hand, it is well known that financial inclusion is lower in less developed countries and the reasons of this situation are associated with various things like low level of financial literacy and religious reasons (Kumar, 2013; Zins and Weill, 2016). Being directly related to financial literacy and structured with religious background, Islamic financial literacy supports financial inclusion. Much of the current works have been done on the conventional financial knowledge and literacy while research on Islamic financial knowledge and literacy are limited. This research trying to explore to what extent do the students/respondents have on Islamic financial knowledge and Islamic financial literacy and its relations with demographic characteristics and entrepreneurship.

First, students' basic, advanced and general Islamic financial knowledge and Islamic financial literacy levels are measured and the results showed that over half of the students have had low level for basic Islamic financial knowledge and Islamic financial literacy in addition to more than two-thirds of students had low level of advanced and general Islamic financial knowledge. Meanwhile, while only about a quarter of students had high level of basic Islamic finance knowledge, the situations got much worse in advanced Islamic financial knowledge, general Islamic financial knowledge and Islamic financial literacy, which were about under fifteen percentage. This indicated that students need to attend and offered more Islamic finance courses and need to be more knowledgeable on Islamic finance. On the other hand, except a few universities (as Business Schools of Düzce and Sakarya Universities and Istanbul University Theology school etc.), most of the higher education institutions put very little emphasis on students' Islamic financial education and literacy. Also, these results resemble previous studies that levels of Islamic financial literacy vary among subgroups of participants (Potrich et al., 2015; Tuna and Ulu, 2016; Çömlekçi 2018).

Second, the differences between the means of financial attitude of students with respect to basic Islamic financial knowledge, advanced Islamic financial knowledge, general Islamic financial knowledge, Islamic financial literacy, and the means of financial behavior of students with respect to basic Islamic financial knowledge, advanced Islamic financial knowledge,, general Islamic financial knowledge and Islamic financial varied and were 
statistically significant. These consequences suggest that students' perceptions towards financial attitude and behavior can be directed when their Islamic financial knowledge and Islamic financial literacy are controlled.

Third, the differences of the means of faculties with respect to basic Islamic financial knowledge, advanced Islamic financial knowledge, general Islamic financial knowledge, Islamic financial literacy varied and statistically significant. This result could be supported the fact that while those students educated form business administration faculty were offered elective Islamic financial course and those students educated from theology faculty prone to Islamic finance themes and questions, engineering students weren't offered either financial and Islamic financial course in general.

Fourth, neither scores of Islamic financial knowledge levels nor Islamic financial literacy showed a difference in terms of gender. These finding can be resulted from having low scores of Islamic financial knowledge levels and Islamic financial literacy in both groups.

Fifth, since the average scores of students those taken at least one Islamic finance course were pretty higher than those not taken at least one Islamic finance course in all Islamic financial knowledge levels and Islamic financial literacy. In the same way, these results also suited completely with the analyzes of scores of those attended at least one Islamic finance activity were higher than those not attended at least one Islamic finance activity. These results implied that offering Islamic financial courses and activities have positively affects Islamic financial knowledge and Islamic financial literacy and therefore financial inclusion (Gedikli and Erdoğan, 2019).

Last but not least, one of the compelling results obtained when investigating the relationship between the situation of looking attractive to entrepreneurship and Islamic financial knowledge levels. According to the investigation, while looking attractiveness did not put a difference on Islamic financial knowledge, it provided a statistically significant relationship between those looking attractive to entrepreneurship and those not looking attractive to entrepreneur with respect to Islamic financial literacy level. Similar to attractiveness to entrepreneurship and Islamic financial knowledge levels and literacy, students' intention to entrepreneurship resulted in the same vein after we made further analyzes to find relationship between those having intention to entrepreneurship and those not having intention to entrepreneurship with respect to Islamic financial knowledge levels and Islamic financial literacy. 
İsmail DURAK, Mehmet Akif ÖNCÜ \& Osman KARTAL

In general, the results postulates that most of the students were low level of Islamic financial knowledge and literacy and these consequences had effects on their financial attitude, financial behavior, status of finding entrepreneurship attractive and intention of entrepreneurship. These results are similar to a large extent with related literature (Chen and Volpe, 2002; Clercq and Vender, 2009; Lusardi et al., 2010; Hafizah and Rahim, 2014; Potrich et al., 2015; Karaa and Kuğu, 2016; Tuna and Ulu, 2016; Çömlekçi, 2017; Biplob and Abdullah 2019).

It is hoped that the findings will contribute to the studies on financial inclusion and Islamic financial literacy. Especially, this study seems to be one of the first studies examining the relationships between Islamic financial literacy and entrepreneurship. The research was carried out only on the basis of undergraduate students. In the future, the situation can be examined with different groups as academicians, public personnel, Islamic banking user etc. to expand the scope of Islamic financial literacy. Overall, in order to increase and improve the level of Islamic financial knowledge and literacy, elective courses should be offered to all faculties, the financial knowledge gap of the theology students and the aspect of theological knowledge of students must be supported by relevant courses, sources and activities.

\section{BIBLIOGRAPHY}

Abdillahi, A. M. (2015). Determinants of Islamic Financial Literacy Towards Retirement Planning. Thesis of Master, School of Economic, Finance and Banking Universiti Utara Malaysia.

Abdullah, M. A., and Anderson, A. (2015). Islamic Financial Literacy among Bankers in Kuala Lumpur. Journal of Emerging Economies and Islamic Research, 3(2), 1-16.

Agarwalla, S.K., Barua, S.K., Jacob, J. and Varma, J.R. (2013), “Financial literacy among working young in urban India”, Working Paper No. 2013-1002, Indian Institute of Management Ahmedabad.

Antara, P. M., Rosidah, M.,\&Hassan, F., (2016). Bridging Islamic Financial Literacy and Halal Literacy: The Way Forward in Halal Ecosystem. Procedia Economics and Finance, 196-202.

Atkinson, A. and Messy, F. (2012), "Measuring financial literacy: results of the OECD/International Network on Financial Education (INFE) Pilot study", Working Paper No. 15, OECD Working Papers on Finance, Insurance and Private Pensions, OECD Publishing, Paris. 
Bekereci, N. E., (2018). İslami Finansal Okuryazarlık: Kahramanmaraş Sütçü İmam Üniversitesi'nde Bir Alan Araştırması. Yüksek Lisans Tezi, Kahramanmaraş Sütçü İmam Üniversitesi Sosyal Bilimler Enstitüsü.

Biplob, H., \& Abdullah, M. F. (2019). The Importance of Islamic Financial Literacy for Muslims: A General Review. Islam and Civilisational Renewal (ICR), 10(1), 106-117.

Chen, H., \& Volpe, R. P. (1998). An analysis of personal financial literacy among college students. Financial services review, 7(2), 107-128.

Chen, H. ve Volpe, R. P. (2002), Gender Differences in Personal Finance Literacy Among College Students, Financial Services Review, 11, pp. $289-307$.

Clercq, de B. ve Venter, JMP. (2009), Factors Influencing A Prospective Chartered Accountant's Level of Financial Literacy: An Exploratory Study, Meditari Accountancy Research, Vol. 17, No. 2, pp. 47 - 60.

Çömlekçi, İ., (2017). İslami Finansal Okuryazarlık Düzeyinin Belirlenmesi: Katılım Bankaları Müşterileri Üzerine Bir Araștırma. Elektronik sosyal bilimler dergisi, 16(63), 1423-1439.

Coşkun, S. (2016). Üniversite öğrencilerinin finansal davranış ve tutumlarının belirlenmesi: Finansal okuryazarlık algıları üzerine bir araştırma. Insan ve toplum bilimleri araştırmaları dergisi, 5(7), 22472258.

Danes, S. M., \& Hira, T. K. (1987, Winter). Money management knowledge of college students. The Journal of Student Financial Aid, 17(1), 4-16.

Er, F., Temizel, F., Özdemir, A., ve Sönmez, H. (2014). Lisans Eğitim Programlarının Finansal Okuryazarlık Düzeyine Etkisinin Araștırılması: Türkiye Örneği. Anadolu Üniversitesi Sosyal Bilimler Dergisi, 14(4), 113-126.

Gedikli, A., \& Erdoğan, S. Malezya'da İslami Finans ve İslami Bankacıllk Uygulamaları Üzerine Bir İnceleme. Bilimname, 2019(38), 251-287.

Hafizah, S., \& Rahim, A. (2014). Psychosocial factors and gender influencing the level of Islamic financial literacy (Doctoral dissertation, Universiti Utara Malaysia).

Hidajat, T., ve Hamdani, M. (2015). Developing Islamic Financial Literacy Index: A Conceptual Paper. The Global Advanced Research Conference on Management and Business Studies.

Karaa, I. E. ve Kuğu, T. D. (2016), Determining Advanced and Basic Financial Literacy Relations and Overconfidence, and Informative Social Media 
İsmail DURAK, Mehmet Akif ÖNCÜ \& Osman KARTAL

Association of University Students in Turkey, Kuram ve Uygulamada Eğitim Bilimleri Dergisi, 16 (6), ss. 1865-1891.

Karakuş, T. F., (2019). "Genel Olarak Finansal Okuryazarlık Ve İslami Finansal Okuryazarlık: Adana İlinde Bir Araştırma”, Doktora Tezi, Çukurova Üniversitesi Sosyal Bilimler Enstitüsü.

Kaya, H., (2019). "Finansal Okuryazarlık Ve İibf'de Verilen Muhasebefinansman Derslerinin Finansal Okuryazarlık Üzerine Etkileri: Cumhuriyet Üniversitesi İ̈BF Öğrencileri Üzerinde Bir Araștırma", Yüksek Lisans Tezi, Cumhuriyet Üniversitesi Sosyal Bilimler Enstitüsü.

Kumar, N. (2013). Financial inclusion and its determinants: evidence from India. Journal of Financial Economic Policy.

Lusardi A., Mitchell O. S. ve Curto, V. (2010), Financial Literacy Among the Young, The Journaol of Consumer Affairs, Vol: 44, No:2, pp. 358 - 380.

Nunnally, J. C. (1967). Psychometric Theory. New York: MacGraw-Hill Book Company.

Organisation for Economic Co-operation and Development (OECD) (2012), OECD/INFE High-Level Principles on National Strategies for Financial Education, OECD Publishing, Paris.

Oseifuah, E. K. (2010), Financial Literacy and Youth Entrepreneurship in South Africa, African Journal of Economic and Management Studies, Vol. 1 No. 2, pp. 164-182

Potrich A.C.G., Vieira, K. M., Coronel D. A. and Filho, R.B. (2015), Financial Literacy in Southern Brazil: Modeling and Invariance Between Genders, Journal of Behavioral and Experimental Finance 6, pp.1 - 12.

Potrich, A. C. G., Vieira, K. M., \& Mendes-Da-Silva, W. (2016). Development of a financial literacy model for university students. Management Research Review, 39(3), 356 - 376.

Şahin, M., \& Barış, S. (2017). Finansal okuryazarlık ve tasarruf davranışları: Kamu çalışanları üzerine bir inceleme. Çankırı Karatekin Üniversitesi İiBF Dergisi, 7(2), 77-103.

Sardiana, A. (2016). The Impact of Literacy to Shariah Financial Service Preferences. Etikonomi, 43-62.

Setiawati, R., Nidar, S. R., Anwar, M., \& Masyita, D. (2018). Islamic Financial Literacy: Construct Process and Validity.Academy of Strategic Management Journal, 17 (4), 1-12. 
Seyrek, İ. H., \& Gül, M., (2017). Finansal Okuryazarlık ve Girişimcilik Niyeti: Üniversite Öğrencileri Üzerine Bir Araştırma. Yönetim ve Ekonomi Araştırmaları dergisi, 15 (2), 103-118.

Siti, H. A., Rosemaliza, A. R., and Hamed, A. B., (2016). Islamic Financial Literacy and its Determinants among University Students: An Exploratory Factor Analysis. International Journal of Economics and Financial Issues, 32-35.

Tuna, G. ve Ulu M.O. (2016), Üniversite Öğrencilerinin Finansal Okuryazarlık Düzeylerini Etkileyen Faktörlerin Belirlenmesi: İşletme Bölümü Öğrencileri Üzerine Bir Araştırma, Uluslararası Yönetim Íktisat ve İşletme Dergisi, ICAFR 16 Özel Sayısı, ss. 128-141.

Türkiye Katılım Bankalar Birliği, (2019). Yaşayan ve Gelişen Katılım Bankacılığı, T.K.B.B. Yayınları, II. Baskı, İstanbul. ISBN: 978-60569523-0-2

Yıldırım, M. V., (2020). "İslami Finansal Okuryazarlık Düzeyinin Belirlenmesi: Tokat Gaziosmanpaşa Üniversitesi Örneği”, Yüksek Lisans Tezi, Tokat Gaziosmanpaşa Üniversitesi Sosyal Bilimler Enstitüsü.

Zins, A., \& Weill, L. (2016). The determinants of financial inclusion in Africa. Review of Development Finance, 6(1), 46-57.

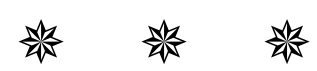




\section{ÜNIVERSITE ÖĞRENCILERININ İSLAMİ FINANSAL OKURYAZARLIĞININ ÖLÇÜLMESİ VE GİRIŞIMCILIIK İLE İLIŞSİsi}

İsmail DURAKa

\author{
Osman KARTALc
}

Mehmet Akif ÖNCÜb

\section{Geniş Öz}

Finansal Erişim, başta dünya bankası olmak üzere birçok araştırmaya konu olmuş finansal sistemin önemli parçalarından biridir. Finansal sisteme dahil olma, gelişmekte olan ve az gelişmiş ülkelerde gelişmiş ülkelere göre daha azdır. Bunun pek çok nedeni olsa da önemli nedenlerinden biri finansal okuryazarlık düzeyinin düşük olmasıdır. Finansal okuryazarlık kavramı, doğru tasarrufları yapmak ve bu tasarrufları doğru yatırımlara yönlendirmek, sermaye ve para piyasaları hakkında bilgi sahibi olmak ve bu bilgileri doğru yorumlamak olarak düşünülebilir. Ayrıca, İslami Finansal Okuryazarlık, İslami finansal sistem hakkında bilgi gerektiren ve finansal erişime olumlu katkı sağlayabilen bir kavramdır. Hayatında İslami kuralları benimsemiş bireyler, faiz duyarlılığının yanı sıra İslami finansal araçlar ve kurumlar hakkında yeterli bilgiye sahip olmadıkça birikimlerini finansal sisteme dahil edemezler. Bu nedenle, insanların İslami finansal okuryazarlık düzeylerinin belirlenmesi, İslami finansal araçlar ve kurumlar hakkındaki bilgi düzeyinin yükseltilmesi hem tasarrufların ekonomiye dahil edilmesi hem de faiz sorununun giderilmesi açısından fayda sağlayacaktır. Literatürde finansal okuryazarlık, cinsiyet, yaș, eğitim, tasarruf davranıșı girişimcilik gibi çeşitli değişkenlerle ilişkilendirilmiştir. Bunların arasında en can alıcı değişkenlerden biri, günümüzde üretime ve istihdama olan katkısı düşünüldüğünde makroekonomik sistemler açısından büyük önem taşıyan girişimciliktir. Hiç şüphesiz girişimcilerin ve girişimci adayları olan üniversite öğrencilerinin finansal bilgi ve okuryazarlık düzeyleri gelecekte katkıda bulunacakları işletmeler açısından çok önem arz eden faktörlerden

a Dr. Öğr. Üyesi, Düzce Üniversitesi, ismaildurak@duzce.edu.tr

b Prof. Dr., Düzce Üniversitesi, mehmetakifoncu@duzce.edu.tr

c Dr. Öğr. Üyesi, Düzce Üniversitesi, osmankartal@duzce.edu.tr 
biridir. Finansal okuryazarlıktan belli açlardan ayrılan bu kavram üzerine çeşitli araştırmalar yapılmıștır. Yapılan bu araştırmanın birkaç amacı vardır. İlk olarak, araştırmanın temel amacı olarak Türkiye'de bir üniversitenin çeşitli fakültelerinde okuyan öğrencilerin İslami finansal okuryazarlık düzeylerinin belirlenmesi amaçlanmıştır. İkinci olarak, İslami finansal okuryazarlık düzeyi ile finansal tutum ve davranış arasındaki ilişkinin incelenmesi amaçlanmıştır. Üçüncüsü, İslami finans okuryazarlığının girişimcilik eğilimi üzerindeki etkisinin tahmin edilmesi amaçlanmıştır. Son olarak, İslami finans okuryazarlığı düzeyinin çeşitli demografik faktörlere göre farklılaşıp farklılaşmadığını, özellikle fakülte değişkeni ve finans ya da İslami finans dersi alıp almamaya göre farklılı̆̆ın belirlenmesi çalışmanın alt amaçları arasındadır. Araştırmanın evreni, Düzce Üniversitesi İşletme, Mühendislik ve İlahiyat fakültelerinin üçüncü ve dördüncü sınıflarında öğrenim gören öğrencilerden oluşmaktadır. Bu üç fakültenin örnek olarak seçilmesinin nedeni, İslami Finans ile yüksek ilişsisi olabilecek İşletme ve İlahiyat Fakültesi ile İslami Finans ile daha az ilişkisi olabilecek bir fakülte öğrencilerinin karşılaştırılması fikridir. Ayrıca öğrencilerin üçüncü ve dördüncü sınıflarının seçilmesinin sebebi, finans, İslami finans ve girişimcilik derslerinin genellikle üçüncü ve dördüncü sınıflarda açılması ve öğrencilerin bu derslerden en az birine bu sınıflara kadar devam etmiş olmalarıdır. Araştırmada örnekleme yapılmış ve kartopu örnekleme yöntemi tercih edilmiştir. Araştırma kapsamında elde edilen 512 anket verisi SPSS 25 paket programı ile analiz edilmiştir. Araştırmada araştırmanın amacına ulaşmak için nicel araştırma yöntemi kullanılmıştır. Analizlerde çalışmanın amaçlarını gerçekleştirmek için frekans, yüzde hesaplama, ortalama ve standart sapma, Cronbach's Alpha, ANOVA, T-testi ve KI-Kare analizleri kullanılmıştır. Öncelikle, finansal tutum, finansal davranış genel İslami finansal bilgi düzeyi ve İslami finansal okuryazarlığın güvenilirlik analizleri yapılmış ve Cronbach's Alpha değeri sırasıyla 0.879, $0.832,0.907$ ve 0.896 olarak bulunmuştur. Ayrıca diğer İslami finansal bilgi düzeylerinin (temel ve ileri düzey) güvenilirlik analizleri hesaplanarak sırasıyla 0.772, 0.888 olarak sonuçlanmıştır. Literatürde güvenirlik katsayısının 0.7 düzeyinin üzerinde olması gerektiği belirtildiğinden bu bağlamda araştırmadan elde edilen verilerin güvenilir olarak kabul edilebileceği söylenebilir. Araştırma sonucunda, öğrencilerin İslami finansal okuryazarlık düzeyi, finansal tutum, finansal davranış ve İslami finansal bilgi düzeyleri anket sorularına verilen cevaplar kullanılarak ölçülmüştür. Elde edilen ölçümler, öğrencilerin İslami Finansal Bilgi ve Okuryazarlık düzeylerinin oldukça düşük olduğunu göstermektedir. Yine de araştırma sonuçları, İslami finans dersleri alan öğrencilerin İslami finans okuryazarlığının yüksek olduğunu göstermiştir. Ayrıca, İslami Finansal Bilgi Düzeyi ile İslami Finans Okuryazarlığı düzeyinin 
İsmail DURAK, Mehmet Akif ÖNCÜ \& Osman KARTAL

fakülte, cinsiyet ve ailenin gelir düzeyine göre önemli ölçüde farklılaştığı sonucuna varılmıştır. Son olarak, girişimciliği çekici bulup bulmama ile ve İslami finansal bilgi arasında bir ilişki çıkmazken, İslami finansal okuryazarlık düzeyi açısından girişimciliği çekici bulanlar ile bulmayanlar arasında istatistiksel olarak anlamlı bir ilişki olduğu sonucu elde edilmiştir. Bulguların finansal erişim, İslami finansal okuryazarlık, girişimcilik eğilimi ve girişimciliği çekici bulup bulmama çalışmalarına katkı sağlayacağı umulmaktadır. Özellikle bu çalışma, İslami finansal okuryazarlık ve girişimcilik arasındaki ilişkileri inceleyen az sayıdaki çalışmalardan biri olduğundan özgün nitelikte olduğu ve ileride konuyla ilgili yapılacak araştırmalara yol gösterici nitelikte olacaktır. Araştırma sadece temelde lisans öğrencilerine yapılması çalışmanın bir kısıtı olarak görülebilir. İleride yapılacak araştırmalarda çalışma evreni olarak akademisyenler, kamu personeli, İslami bankacılık kullanıcıları vb. farklı grupların da incelenmesi İslami finansal okuryazarlığın kapsamını farklı gruplarda görüp genişletmek açısından önemlidir. Genel olarak değerlendirildiğinde, İslami finansal bilgi ve okuryazarlık düzeyini artırmak ve iyileştirmek için tüm fakültelere bu alanlarla ilgili seçmeli dersler konulmalıdır, Buna ek olarak, ilahiyat fakültesi öğrencilerinin finansal bilgi açığı, işletme öğrencilerin ilahiyat bilgisi açığı ve diğer fakülte öğrencilerinin hem ilahiyat hem finansal bilgi açı̆̆ının kapatılması için fakültelere seçmeli dersler, kütüphanelerde öğrencilere sunulabilecek çeşitli kaynaklar ve düzenlenebilecek panel, sempozyum gibi faaliyetlerle öğrencilerin desteklenmesi faydalı olacaktır.

Anahtar Kelimeler: İslami Ekonomi, İslami Finans Okuryazarlık, İslami Finans Bilgisi, Girişimcilik Niyeti, Girişimcilik Eğilimi, İstatistiksel Ölçüm.

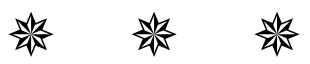

